\title{
Scientific evidence on cultural influence in child care
}

\author{
Evidências científicas sobre a influência cultural nos cuidados às crianças
}

Isabella Joyce Silva de Almeida ${ }^{1}$, Bruna de Souza Buarque ${ }^{1}$, Tatiane Gomes Guedes ${ }^{1}$, Gabriela Cunha Schechtman Sette $^{1}$, Ana Márcia Tenório de Souza Cavalcanti ${ }^{1}$

Objective: to analyze the scientific evidence on cultural influence in child care. Methods: integrative review of the literature with metassynthesis, carried out in six databases, without limits regarding the year of publication, using the descriptors "Culture" and "Child Care", in the Portuguese, English and Spanish languages. Data evaluated were through content analysis and in light of the constructs of Leininger's theory. Results: seven articles were selected, from which two categories emerged: interface between professional care systems and culture; and interface between generic care systems and culture. Conclusion: culture influences the general care given to children, especially related to respiratory problems, malnutrition and burns. The use of medicinal plants, homemade teas and taking to a folk healer are examples of popular practices that permeate the routine of care provided to children.

Descriptors: Culture; Child Care; Nursing Theory.

Objetivo: analisar as evidências científicas sobre a influência cultural nos cuidados às crianças. Métodos: revisão integrativa da literatura com metassíntese, realizada em seis bases de dados, sem limites quanto ao ano de publicação, utilizando os descritores "Cultura" e "Cuidado da Criança", nas línguas portuguesa, inglesa e espanhola. Dados avaliados por meio da análise de conteúdo e à luz dos constructos da teoria de Leininger. Resultados: sete artigos foram selecionados, dos quais emergiram duas categorias: a interface entre os sistemas de cuidados profissionais e cultura; e a interface entre os sistemas de cuidados genéricos e cultura. Conclusão: a cultura influencia nos cuidados genéricos prestados às crianças, sobretudo, relacionados a problemas respiratórios, desnutrição e queimaduras. A utilização de plantas medicinais, chás caseiros e benzeduras são exemplos de práticas populares que permeiam a rotina de cuidados dispensados às crianças.

Descritores: Cultura; Cuidado da Criança; Teoria de Enfermagem.

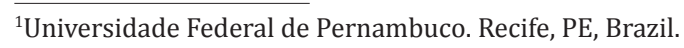




\section{Introduction}

The right to life, health, food, education, sports, leisure, and others must be assured ${ }^{(1)}$ for children, who are considered as such by law up to 12 incomplete years of age.

Care, considered intrinsic to the human being, consists of actions permeated with zeal to the other. In this sense, the presence of a child is usually an event that generates the need for the human being to assume this primitive role of being careful, which is ingrained with the way of raising families ${ }^{(2-3)}$.

Culture plays an important role in caring for children. Hygiene, eating habits, weaning and the use of medicinal plants are examples of practices influenced by cultural values, seized between generations, that guide the daily routine of generic care provided to children ${ }^{(4-5)}$.

In this way, the vision about the care directed to the child goes through several scopes, with highlight to the cultural one. Based on Nursing's cultural nursing theory, by nurse Madeleine Leininger, culture encompasses beliefs, values and life routines of a given group, which are learned, incorporated and transmitted to the generations, being, therefore, guiding elements of behavioral patterns in face of the various situations ${ }^{(6)}$.

Expressions such as "daily routine", "popular knowledge" and "population's experience" have been present in studies and translated the culture of a people. In particular, the relationship between culture and child care is highlighted ${ }^{(7-13)}$.

It is necessary, therefore, that professionals develop the care provided to children based on cultural competence, defined as the ability to understand the cultural peculiarities of each individual and, thus, provide quality care. The nurse, a prime caretaker, should develop this competence, favoring the appreciation of the real needs of the child population ${ }^{(14)}$.

It is therefore necessary for nurses to consider the constructs of the aforementioned theory, such as the world view, the cultural and social structure di- mensions, the environmental context and the generic care systems, so that, according to them, an effective care is established ${ }^{(6)}$.

In view of the above, the present study aimed to analyze the scientific evidence on cultural influence in the care of children.

\section{Methods}

This is an integrative review with metassynthesis, which consists of the selection of data extracted from scientific bases pertinent to the research objective; elaboration of a coherent description of certain phenomena; aggregation of data; elaboration of a new interpretation of the results, making inference from the articles selected in the research; appreciation of the researcher on the initial interpretations; and final formulation of new interpretations ${ }^{(15-16)}$

The present study took place in January 2016, considering the guiding question: what is the influence of culture on the care provided to children? This was elaborated according to the PICO strategy (P - Patient, Problem or Group; I - Intervention; C - Control or Comparison, defined as a standard intervention, most used intervention or no intervention; and 0 Outcomes), which is used to formulate well-developed research questions. In this study, the following elements identified were: P - children; I - the influence of culture; C - no intervention; and $\mathrm{O}$ - care $^{(17)}$.

The literature search was carried out using the descriptors "Culture" and "Child Care", in the Portuguese, English and Spanish languages, performing the crosses in pairs, with the Boolean operator "AND", standardized by Medical Subject Heading (MeSH) and Descritores em Ciências da Saúde (DeCS). The selected databases were Cumulative Index to Nursing and Allied Health Literature (CINAHL), Literatura Latino-Americana e do Caribe em Ciências da Saúde (LILACS), Bases de Dados de Enfermagem (BDENF), Base de dados da Fundacíon Index - España (CUIDEN), Scopus Info Site (SCOPUS) and Scientific Electronic Library Online (SCIELO). 
We included studies available in Portuguese, English and Spanish languages that answered the guiding question. Research abstracts, review articles, book chapters, theses, dissertations, editorials and newspaper articles were excluded; there were no limits established for the year of publication due to the intention to contemplate cultural influence present historically in the care of children.

The initial selection of articles occurred through the reading of titles and abstracts, followed by reading them in full. The articles in duplicate were inserted only once and, in this case, the database chosen was the one with the greatest number of articles in the crosses. A total of 2,149 studies were found. After reading and following the inclusion and exclusion criteria, seven articles were selected.
Then, the content analysis was used ${ }^{(18)}$, considering the phases of pre-analysis, exploration of the material, treatment and interpretation of the results. The final phase was carried out in the light of Leininger's constructs: cultural dimensions and social structure; the environmental context; ethno-history; generic care systems; professional care systems; and cultural care ${ }^{(6,18)}$. From the analysis of the articles and in the light of the constructs of cultural care theory, two categories emerged: 1) interface between professional care systems and culture ${ }^{(7,10-13)}$; and 2) interface between generic care systems and culture ${ }^{(7-11)}$.

\section{Results}

The summary of the main extracted data is in Figure 1.

\begin{tabular}{|c|c|c|c|}
\hline Titles of articles & $\begin{array}{c}\text { Areas of } \\
\text { publication }\end{array}$ & Objectives & Types of study \\
\hline $\begin{array}{l}\text { Culture in family care for the child } \\
\text { victim of burns }\end{array}$ & Nursing & $\begin{array}{l}\text { To understand how beliefs and values influence the } \\
\text { care of children who had been victims of burns }\end{array}$ & Ethnographic \\
\hline $\begin{array}{l}\text { Cultural aspects in family care for } \\
\text { children with malnutrition }\end{array}$ & Nursing & $\begin{array}{l}\text { To identify the cultural factor that interferes in the } \\
\text { care of malnourished children and to propose actions } \\
\text { of popular education in health for the care of these } \\
\text { children }\end{array}$ & Action-research \\
\hline $\begin{array}{l}\text { Beliefs and cultural values of } \\
\text { malnourished children's family }\end{array}$ & Nursing & $\begin{array}{l}\text { To identify and analyze mothers' meanings in the } \\
\text { care of malnourished children }\end{array}$ & Ethnographic \\
\hline $\begin{array}{l}\text { Socioeconomic and cultural factors } \\
\text { of maternal care in childhood } \\
\text { respiratory disease }\end{array}$ & Nursing & $\begin{array}{l}\text { To understand the social, economic, and cultural } \\
\text { factors of maternal care in respiratory disease }\end{array}$ & Ethnographic \\
\hline $\begin{array}{l}\text { Interculturality in pediatrics: } \\
\text { traditional beliefs in child health in } \\
\text { a rural area }\end{array}$ & Medicine & $\begin{array}{l}\text { To establish the meaning of mothers/caregivers' } \\
\text { traditional beliefs with the care they take towards } \\
\text { child health in a rural area }\end{array}$ & $\begin{array}{l}\text { Case study with qualitative } \\
\text { approach }\end{array}$ \\
\hline $\begin{array}{l}\text { Medicinal plants in the treatment } \\
\text { of childhood respiratory diseases: } \\
\text { a vision of popular knowledge }\end{array}$ & Nursing & $\begin{array}{l}\text { To investigate the use of popular knowledge on the } \\
\text { use of medicinal plants in the treatment of childhood } \\
\text { respiratory diseases }\end{array}$ & $\begin{array}{l}\text { Descriptive and exploratory, } \\
\text { with qualitative approach }\end{array}$ \\
\hline $\begin{array}{l}\text { Popular practices adopted in child } \\
\text { health care }\end{array}$ & Nursing & $\begin{array}{l}\text { To identify the main popular resources used in child } \\
\text { care }\end{array}$ & $\begin{array}{l}\text { Descriptive and exploratory, } \\
\text { with qualitative approach }\end{array}$ \\
\hline
\end{tabular}

Figure 1 - Summary of key data from selected articles 
The studies had a qualitative approach. It is pertinent to emphasize that this approach gives to the study perceptions that pass through data not measurable by number, and include symbolic elements that are extracted through, among others, speeches, field observations and artistic production, capturing peculiarities and details present in this universe.

Still on the type of study, the presence of ethnographic studies stood out. Some of them introduce ethnography as a method in consonance with ethno-nursing, a construct of the theory of cultural care, proposed by the nurse Madeleine Leininger. Both the ethnographic method and the ethno-cultural construct guide research conducted primarily in the field, bringing the researcher closer to the reality, customs, beliefs, daily life and values of the research participants, which facilitates focusing on the cultural context.

\section{Discussion}

This review presents as a limitation the small number of studies on the proposed theme, making it difficult to perform comparisons and generalizations. Despite the number of articles found, this research encourages further publications, strengthening the need for reflection on the cultural aspects involved in child care.

In the category Interface between professional care systems and culture, the term professional care systems is a construct belonging to Leininger's theory, which defines this kind of care as that provided by people with technical skills, who have received training from a formal teaching, which bases knowledge on health, illness and well-being ${ }^{(6)}$.

It is essential, in this sense, to highlight the term "cultural competence" in the context of the interface between professional care and culture, considered as a continuous process, in which the practitioner seeks to be more and more self-conscious, aiming at knowledge and appreciation of culture in the universe in which care is provided, favoring the provision of holistic and effective care $\mathrm{e}^{(14,19)}$.

Studies have pointed to the need to incorporate cultural considerations in the face of care, since respect, appreciation of the environmental context, ethno-history and cultural dimensions and social structure bring the professional closer to the individual. Awareness about the particularities of a people preserves culture within care and raises the chances of therapeutic practices with more credibility and acceptance, which provides congruent cultural care $\mathrm{e}^{(7,10-13)}$.

Therefore, for the development of cultural competence, transculturality, preached by the theory of cultural care, must be incorporated into professional actions. Empathy and flexibility must permeate attitudes, and it is imperative to develop awareness of cultural differences in the conduction of an appropriate cultural assessment. In this sense, the universality of care is established, since the peculiarities, whether of the majority or minority, are weighted against the dealings with the public ${ }^{(14)}$.

The positive and necessary relationship between cultural competence and health education is emphasized. In order to build knowledge, it is necessary to incorporate details rooted in customs and traditions to whom this practice is destined. So, the association between these two aforementioned elements enables an approximation with the reality of child care, which favors holistic approach, timely therapeutic guidelines and humanistic care ${ }^{(20)}$.

The interface between care and culture, evident in this study, corroborates the National Humanization Policy of the Unified Health System (SUS), popularly known as "Humaniza SUS", which appreciates the different subjects involved in the health production process, considering the social, ethical, educational and psychic aspects, entangled in the culture, that make up the health determinants. Thus, it is necessary to make room for the major role of the user in the care process, contributing to an effective "construction of health"(21).

It is essential to rethink practitioners' conduct. Conceptions of authoritarianism and supremacy of 
knowledge lead to utopian care, which does not transcend the walls of health institutions ${ }^{(22)}$.

From the above, for professionals to be able to ponder the peculiarities of the individual and the community, it is indispensable the insertion in this context during the training period. However, there is no consensus regarding the approach to subjectivity in nurses' education, which points out the need for a reorientation in the National Curricular Guidelines, aiming at putting it in line with important health policy guidelines in Brazil, such as the National Humanization Policy ${ }^{(23)}$.

About the category Interface between generic care systems and culture, its meaning, according to Leininger's theory, shows that empirical knowledge perpetuated through tradition is transmitted as a way of guiding individuals and groups towards care, taking into account improvement of health conditions or dealing with situations of death or disability ${ }^{(6)}$.

In this sense, generic care is the care provided by caregivers who do not have the scientific training to do so, but who perform this activity on a daily basis. It is relevant to understand that this care has an unspeakable cultural burden, since each family has the proper form of taking care of its members ${ }^{(24)}$.

For this reason, researches have focused on studying the interference of culture with the care provided to children. Investigations have focused mainly on the care of health problems, such as respiratory infection, malnutrition and burns ${ }^{(7-11)}$.

Care, considered as inherent to the mother/ woman, is justified by the social construction of the role of women in society, in which she is the one who mainly provides care, protection and education of the children. Just as there is a predestined role for care, there are patterns of care procedures in this universe, such as the use of medicinal plants, homemade teas and folk healers ${ }^{(12-13)}$.

In view of this, it is understood that care occurs in the network of symbols and meanings that weave dynamics and family relationships, creating specific rituals of each people. These rites are the vehicles by which empirical knowledge is transmitted from generation to generation. In this way, there are customs that by the professional optics are harmful to health; however, it is difficult to change them, since they come from a historical social construction ${ }^{(25)}$.

Regarding the main health problems treated together with culture, we highlight malnutrition. Food is much more than the nutritional aspect. It is related to the philosophical, social and cultural aspects of the population. Empirical knowledge is tied to food, to the form of preparation, including the amount ingested. It is evident that cultural aspects influence the customs of the population and, consequently, the behavior towards health conditioners and the health-disease process $^{(14)}$. These findings corroborate a study that dealt with the different nuances generated by the dialogue between cultural aspects and food within society ${ }^{(26)}$.

Popular and professional systems need to be inextricably linked when seeking consistent cultural care. It is necessary to respect the reality in which the caregivers are inserted and, along with these, to build an adjusted care between the popular and scientific interests.

Thus, the scientific evidence explained in this study encourages nurses to adopt health care that considers the cultural context in which these children are inserted. In addition, this study fosters the applicability of theories, such as that of Madeleine Leininger, which contributes to the recognition of the real needs and specificities of the population cared for, providing scientific support to nursing.

\section{Conclusion}

Culture influences the generic care given to children, especially related to respiratory problems, malnutrition and burns. The use of medicinal plants, homemade teas and folk healers are examples of popular practices that permeate the routine of care provided to children. 


\section{Collaborations}

Almeida IJS contributed to the conception and design, analysis and interpretation of data and the writing of the article. Buarque BS contributed to the conception and design. Guedes TG contributed to the relevant critical review of intellectual content. Sette GCS contributed to the final approval of the version to be published. Cavalcanti AMTS contributed to the conception and design, relevant critical review of the intellectual content and final approval of the version to be published.

\section{References}

1. Presidência da República (BR). Lei n. 8.069, de 13 de julho de 1990. Dispõe sobre o Estatuto da criança e do adolescente e dá outras providências [Internet]. 1990 [citado 2017 jan. 18]. Disponível em: http://www.planalto.gov.br/ccivil_03/leis/ L8069.htm

2. Santos JS, Andrade RD, Pina JC, Veríssimo MLOR, Chiesa AM, Mello DF. Child care and health rights: perspectives of adolescent mothers. Rev Esc Enferm USP. 2015; 49(5):73340. doi: http://dx.doi.org/10.1590/S0080623420150000500004

3. Boff L. 0 cuidado essencial: princípio de um novo ethos. Inclusão Soc [Internet]. 2015 [citado 2017 jan. 16]; 1(1):28-35. Disponível em: http://revista. ibict.br/inclusao/article/view/1503/1690

4. Maia SMS, Silva LR. Saberes e práticas de mães ribeirinhas e o cuidado dos filhos recémnascidos: contribuição para a enfermagem. Rev Enferm Ref 2012; 3(7):131-8. doi: https://dx.doi. org/10.12707/RIII11130

5. Miranda DB, Marostica FC, Matão MEL. Influência do fator cultural no processo de cuidado puerperal. Rev Eletr Gestão Saúde. 2015; 3(6):2444-59. doi: http://dx.doi.org/10.18673/gs.v6i3.22393

6. Leininger MM. Culture care diversity and universality. New York: National Leangue for Nursing; 2015.
7. Brito MEM, Damasceno AKC, Pinheiro PNC, Vieira LJES. A cultura no cuidado familiar à criança vítima de queimaduras. Rev Eletr Enferm. 2010; 12(2):321-5. doi: http://dx.doi.org/10.5216/ree. v12i2.7457

8. Silva MDB, Silva LR, Reis AT, Santos IMM, Silva LR. Socioeconomic and cultural factors of maternal care in children's respiratory disease. Rev Enferm UFPE on line [Internet]. 2012 [cited 2017 Jan. 16]; 6(10):2335-41. Available from: http://www. revista.ufpe.br/revistaenfermagem/index.php/ revista/article/view/2898/pdf_1507

9. Frota MA, Sousa RMV, Barroso MGT. Beliefs and cultural values of the undernourished child's family. Acta Paul Enferm. 2008; 21(1):1016.doi:http://dx.doi.org/10.1590/S010321002008000100016

10. Frota MA, Martins MC, Albuquerque CM. Aspectos culturais no cuidado familiar à criança com desnutrição. Acta Scientiarium Health Sci. 2009; 31(1):9-14. doi: http://dx.doi.org/10.4025/ actascihealthsci.v31i1.4519

11. Torrado OC, Casadiego CD, Castellanos MG. Interculturalidad em pediatria: creencias tradicionales em la salud infantil em un área rural. Rev Col Enferm [Internet]. 2011 [citado 2017 jan. 16]; 6(6):82-9. Disponible en: https://dialnet.unirioja. es/servlet/articulo?codigo $=4036656$

12. Souza MA, Melo MB, Silveira Júnior RS, Barbosa MA, Siqueira KM, Martins CA, et al. Práticas populares adotadas nos cuidados em saúde da criança. Rev Enferm UERJ [Internet]. 2006 [citado 2017 jan. 16]; 14(4):512-7. Disponível em: http:// www.facenf.uerj.br/v14n4/v14n4a04.pdf

13. Araújo KRM, Kerntopf MR, Oliveira DR, Menezes IRA, Brito Júnior FE. Plantas medicinais no tratamento de doenças respiratórias na infância: uma visão do saber popular. Rev Rene [Internet]. 2012 [citado 2017 jan. 16]; 13(3):659-66. Disponível em: http//www.revistarene.ufc.br/revista/index. php/revista/article/view/733/pdf_1

14. Vilelas JMS, Janeiro SID. Transculturalidade: o enfermeiro com competência cultural. Rev Min Enferm [Internet]. 2012 [citado 2017 jan. 16]; 16(1):120-7. Disponível em: http://www.reme. org.br/artigo/detalhes/509 
15. Soares CB, Hoga LAK, PM, Sangaleti C, Yonekura $\mathrm{T}$, Silva DRAD. Integrative review: concepts and methods used in nursing. Rev Esc Enferm USP. 2014; 48(2):335-45. doi:https://dx.doi. org/10.1590/S0080-6234201400002000020

16. Polit DF, Beck CT. Fundamentos da pesquisa em enfermagem: avaliação de evidências para a prática de enfermagem. Porto Alegre: Artmed; 2011.

17. Santos CMC, Pimenta CAM, Nobre MRC. The PICO strategy for the research question construction and evidence search. Rev Latino-Am Enfermagem. 2007; 15(3):508-11. doi: http://dx.doi. org/10.1590/S0104-11692007000300023

18. Bardin L. Análise de conteúdo. Lisboa: Edições 70; 2011.

19. Araújo TAM, Vasconcelos ACCP, Pessoa TRF, Forte FDS. Multiprofissionalidade e interprofissionalidade em uma residência hospitalar: o olhar de residentes e preceptores. Interface Comunic Saúde Educ. 2017; 21(62):601-13. doi: https:// dx.doi.org/10.1590/1807-57622016.0295

20. Gomez SS, Moya JLM. Interactions between the epistemological perspective of nursing educators and participants in educational programs: limits and opportunities toward the development of qualification processes for the promotion of self-care in health. Texto Contexto Enferm. 2015; 24(2):301-9. doi: http://dx.doi. org/10.1590/0104-07072015000012014
21. Martins CP, Luzio CA. HumanizaSUS policy: anchoring a ship in space. Interface (Botucatu). 2017; 21(60):13-22. doi: http://dx.doi. org/10.1590/1807-57622015.0614

22. Vasconcelos MFF, Nicolotti CA, Silva JF, Pereira SMLR. Entre políticas (EPS - Educação Permanente em Saúde e PNH - Política Nacional de Humanização): por um modo de formar no/para o Sistema Único de Saúde (SUS). Interface Comunic Saúde Educ. 2016; 20(59):981-91. doi: https:// dx.doi.org/10.1590/1807-57622015.0707

23. Carvalho NM, Nery IS, Campelo V, Barbosa VRA. The teaching of humanization in the nursing bachelor course in a public university Rev Enferm UFPE on line [Internet]. 2016 [cited 9 Nov. 2017]; 10(12):4554-562. Available from:: http://www. revista.ufpe.br/revistaenfermagem/index.php/ revista/article/view/9991/pdf_1848

24. Ceolin T, Heck RM, Barbieri RL, Schwartz E, Muniz RM, Pillon CN. Medicinal plants: knowledge transmission in families of ecological farmers in Souther Rio Grande do Sul. Rev Esc Enferm USP. 2011; 45(1):47-54. doi: http://dx.doi. org/10.1590/S0080-62342011000100007

25. Bernal ZD, Guerra TA, Xiomara LM. La antropología médica aplicada a la salud pública. Rev Cubana Salud Pública [Internet]. 2015 [citado 2017 nov. 4]; 41(4):655-65. Disponible en: http://scielo.sld. cu/pdf/rcsp/v41n4/spu09415.pdf

26. Maciel RA. Alimentação, sociedade e cultura. Horiz Antropol. 2012; 18(38):403-6. doi: https://dx.doi. org/10.1590/S0104-71832012000200018 